
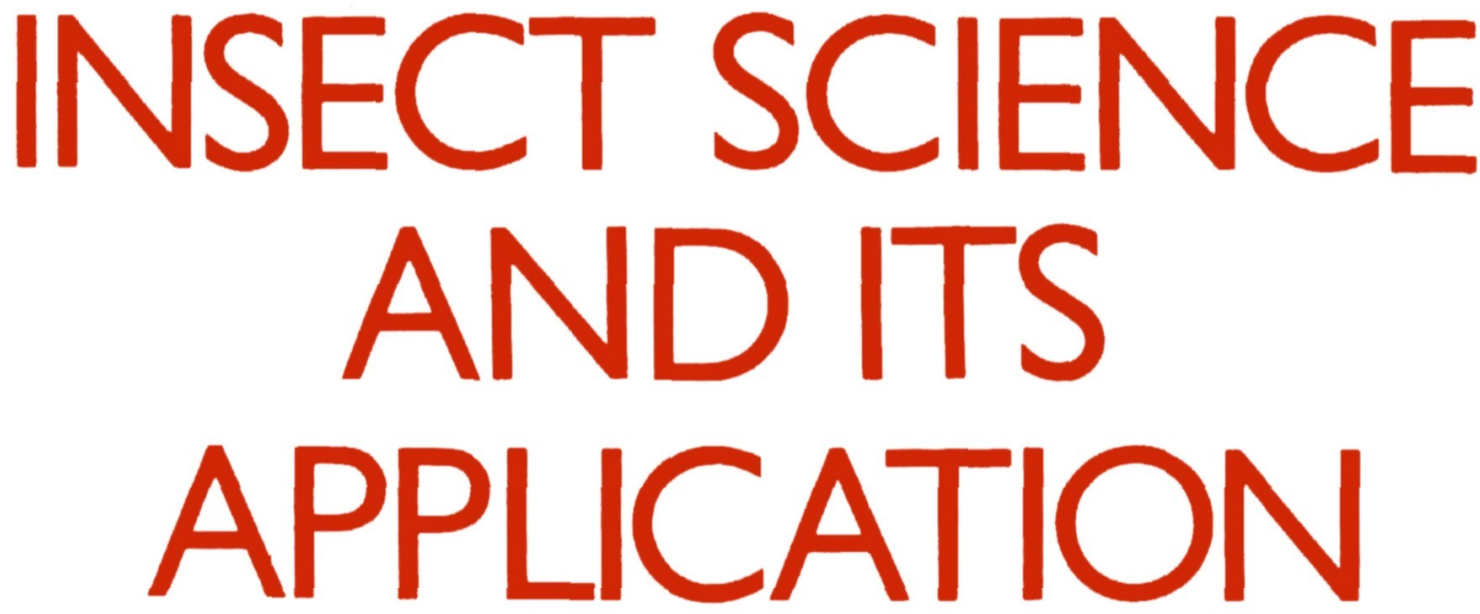

The International Journal of Tropical Insect Science

\author{
Editor: Thomas R Odhiambo \\ International Centre of Insect Physiology and Ecology (KIPE)
}

THIS ISSUE. CONTAINS A SPECIAL SECTION ON LEISHMANIASIS EPIDEMIOLOGY

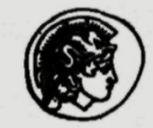

\title{
PERGAMON PRESS
}

OXFORD · NEW YORK - BEIJING · FRANKFURT · SÃO PAULO

SYDNEY - TOKYO - TORONTO 


\title{
Insect Science and its Application
}

\author{
The International Journal of Tropical Insect Science
}

Sponsored by the International Centre of Insect Physiology and Ecology (ICIPE), and the African Association of Insect Scientists (AAIS)

\section{Editor-in-Chief \\ Thomas R. Odhiambo}

International Centre of Insect Physiology and Ecology (ICIPE), P.O. Box 30772, Nairobi, Kenya

\section{Editorial Advisory Board}

F. T. Abu Shama, Kuwait, State of Kuwait

P. L. Adkisson, Texas, U.S.A.

G. Benz, Zurich, Switzerland

J. C. M. Carvalho,

Rio de Janeiro, Brazil

I. Fagoonee, Reduit, Mauritius

R. Galun, Jerusalem, Israel

T. Hidaka, Kyoto, Japan

H. Hirumi, Nairobi, Kenya
A. G. Ibrahim, Kuala Lumpur, Malaysia

V. Landa, Prague, Czechoslovakia

M. Locke, Ontario, Canada

J. R. Mainoya, Dar es Salaam,

Tanzania

A. Mansingh, Kingston, Jamaica

F. G. Maxwell, Texas, U.S.A.

J. Meinwald, New York, U.S.A.

P. L. Miller, Oxford, England
J. Mouchet, Paris, France

M. D. Pathak, Manila,

The Philippines

K. N. Saxena, Mbita, South Nyanza, Kenya

L. M. Schoonhoven, Wageningen, The Netherlands

J. E. Treherne, Cambridge, England

A. Youdeowei, Ibadan, Nigeria

\section{PUBLISHED BIMONTHLY}

Publishing Office:

Journals Production Unit, Pergamon Journals Ltd, Hennock Road, Marsh Barton, Exeter, Devon EX2 8NE [Tel. Exeter (0392) 51558; Telex 42749]

Subscription and Advertising Office:

Headington Hill Hall, Oxford OX3 0BW, U.K. [Tel. Oxford (0865) 64881]

\section{Annual Subscription Rate 1986}

For libraries, university departments, government laboratories, industrial and other multiple-reader institutions, US\$165.00; 2-year rate (1986-87) US\$313.50 (including postage and insurance). Specially Reduced Rates for Individuals; in the interest of maximizing the dissemination of the research results published in this important international journal we have established a two-tier price structure. Any individual whose institution takes out a library subscription may purchase a second or additional subscriptions for personal use at a much reduced rate of US\$60.00. Members of the International Centre of Insect Physiology and Ecology (ICIPE) and the African Association of Insect Scientists (AAIS) may purchase a subscription at the special rate of US\$20.00. Subscription enquiries from customers in North America should be sent to: Pergamon Journals Inc., Maxwell House, Fairview Park, Elmsford, NY 10523, U.S.A., and for the remainder of the world to: Pergamon Journals Ltd, Headington Hill Hall, Oxford OX3 0BW, U.K.

Application forms for Membership of the AAIS (subscription US\$20.00) may be obtained from: Hon. Secretary, African Association of Insect Scientists, P.O. Box 59900, Nairobi, Kenya.

Prices are subject to amendment without notice.

Microform Subscriptions and Back Issues

Current subscriptions are available on microfiche simultaneously with the paper editions and on microfilm on completion of the annual index at the end of the subscription year.

\section{Copyright (C) 1986 Pergamon Journals Limited}

It is a condition of publication that manuscripts submitted to this journal have not been published and will not be simultaneously submitted or published elsewhere. By submitting a manuscript, the authors agree that the copyright for their article is transferred to the publisher if and when the article is accepted for publication. However, assignment of copyright is not required from authors who work for organizations which do not permit such assignment. The copyright covers the exclusive rights to reproduce and distribute the article, including reprints, photographic reproductions, microform or any other reproductions of similar nature and translations. No part of this publication may be reproduced, stored in a retrieval system or transmitted in any form or by any means, electronic, electrostatic, magnetic tape, mechanical, photocopying, recording or otherwise, without permission in writing from the copyright holder.

Photocopying Information for Users in the U.S.A.

The Item-fee Code for this publication indicates that authorization to photocopy items for internal or personal use is granted by the copyright holder for libraries and other users registered with the Copyright Clearance Center (CCC) Transactional Reporting Service provided the stated fee for copying beyond that permitted by Section 107 or 108 of the U.S. Copyright Law is paid. The appropriate remittance of $\$ 3.00$ per copy per article is paid directly to the Copyright Clearance Center Inc., 27 Congress Street, Salem, MA 01970.

Permisaion for Other Use

The copyright owner's consent does not extend to copying for general distribution, for promotion, for creating new works, or for resale. Specific written permission must be obtained from the publisher for such copying. 